\title{
IDENTIFIKASI PERSEPSI RESPONDEN TERHADAP WISATA ALAM PUSRI, DANAU RANAU OKU SELATAN, PROVINSI SUMATERA SELATAN
}

\section{IDENTIFICATION OF RESPONDENTS' PERCEPTION OF PUSRI NATURAL TOURISM, LAKE RANAU OKU SELATAN, SOUTH SUMATRA PROVINCE}

\author{
Eko Setiyawan, Gunardi Djoko Winarno, Yulia Rahma Fitriana, Slamet Budi Yuwono \\ Jurusan Kehutanan, Fakultas Pertanian, Universitas Lampung \\ Jln. Prof. Dr. Soemantri Brojonegoro No. 1 Gedung Meneng, Bandar Lampung \\ *e-mail: ekosetiyawan1030@gmail.com
}

\begin{abstract}
The tourist's perception is essential in developing tourism as a base on decision-making for tourism management. The purpose of this study was to identify respondents' perception of facilities and services, accommodation, infrastructure, nature, and environment in Pusri Lake Ranau Nature Tourism. Data collection was implemented by direct observation method and closed interview questionnaire. The data obtained is then descriptively qualitatively analyzed. The results showed that respondents' perceptions gave a varied assessment of Pusri Danau Ranau Nature Tourism for each aspect of the assessment, including natural and environmental aspects of 3.91 (quite good), accommodation aspect of 3.45 (quite good), infrastructure aspect of 3.22 (quite good) and aspects of facilities and services of 3.38 (quite good). The element that must be looked at is in the environmental hygiene sector because respondents are still not satisfied with the element, which can be seen from the average value of cleanliness of 2.91 (not good), waste management of 2.71 (not good), and toilets of 2.54 (not good). Environmental cleanliness needs to be considered so that tourism remains beautiful and the improvement of facilities such as the procurement of garbage boxes.
\end{abstract}

Keywords: Pusri nature tourism, Perception of tourists, Cleanliness of the environment.

\begin{abstract}
ABSTRAK
Persepsi wisatawan sangat penting dalam pengembangan wisata karena sebagai dasar pengambilan keputusan bagi pihak pengelola wisata. Tujuan dari penelitian ini adalah indentifikasi persepsi responden terhadap aspek fasilitas dan pelayanan, akomodasi, infrastruktur, alam dan lingkungan di Wisata Alam Pusri Danau Ranau. Pengambilan data dilakukan dengan metode observasi langsung dan kuesioner wawancara tertutup. Data yang diperoleh kemudian dianalisis secara deskriptif kualitatif. Hasil penelitian menunjukkan persepsi responden memberikan penilaian yang bervariasi terhadap Wisata Alam Pusri Danau Ranau untuk setiap aspek penilaian diantaranya: aspek alam dan lingkungan sebesar 3,91 (cukup baik), aspek akomodasari sebesar 3,45 (cukup baik), aspek infrastruktur sebesar 3,22 (cukup baik) dan aspek fasilitas dan pelayanan sebesar 3,38 (cukup baik). Unsur yang harus diperhatkan yaitu pada sektor kebersihan lingkungan karena responden masih belum puas terhadap unsur tersebut yang mana dapat dilihat dari hasil nilai rata-rata terhadap kebersihan
\end{abstract}


sebesar 2,91 (tidak baik) sedangkan pengelolaan sampah sebesar 2,71 (tidak baik) dan toilet sebesar 2,54 (tidak baik). Kebersihan lingkungan perlu diperhatikan agar wisata tetap indah serta pembenahan fasilitas seperti pengadaan kotak sampah.

Kata kunci: Wisata alam Pusri, Persepsi wisatawan, Kebersihan lingkungan.

\section{PENDAHULUAN}

Indonesia memiliki potensi ekowisata yang sangat baik berkat keindahan alam dan keberagaman adat. Sektor wisata berkembang menjadi salah satu industri terbesar di tingkat global dengan memberikan banyak manfaat (Oktaviantari et al., 2019). Secara langsung, kepariwisataan menciptakan lapangan kerja bagi masyarakat sekitar wisata, menekan angka pengangguran dan kemiskinan serta meningkatkan devisa negara (Sari et al., 2018). Provinsi Sumatera Selatan memiliki potensi wisata yang baik untuk dikembangkan. Peningkatan potensi pariwisata yang berkembang saat ini perlu untuk diperhatikan dan dilakukan dengan penanganan yang profesional (Yumsinah, 2017). Pemerintah Kabupaten Ogan Kemiring Ulu (OKA) Selatan mengembangkan pariwisata yang ada didaerahnya yaitu Danau Ranau. Danau Ranau merupakan danau terbesar kedua di pulau Sumatera, secara geografis wilayahnya terletak antara Kabupaten Ogan Kemiring Ulu Selatan Provinsi Sumatera Selatan dan Kabupaten Lampung Barat Provinsi Lampung (Prasetya \& Ansar, 2017).

Wisata Danau Ranau banyak menyajikan berbagai pertunjukan alam yang menarik dari indahnya Danau Ranau dan Gunung Seminung. Menurut Rosida (2018), objek wisata alam merupakan potensi yang menjadi pendorong kehadiran wisatawan kesuatu daerah tujuan wisata. Terdapat salah satu objek destinasi wisata alam di Danau Ranau yaitu objek Wisata Alam Pusri Danau Ranau. Wisata Alam Pusri Danau Ranau telah menawarkan berbagai aspek-aspek pendukung wisata yang menjadi pendukung wisatawan dalam berwisata dikawasan Danau Ranau. Komponen produk wisata berupa attraction, amenity, accessibility, akomodasi, dan kelembagaan mempengaruhi potensi dan pengembangan suatu wisata (Setiawan, 2015).

Persepsi pengunjung merupakan hal yang penting dalam pengembangan suatu destinasi pariwisata. Persepsi adalah proses yang digunakan oleh individu untuk menginterprestasikan masukkan informasi guna menciptakan gambaran dunia yang memiliki arti (Kotler, 2005). Mengenai apa yang diminati, diingini, dan diharapkan oleh pengunjung kesuatu destinasi menjadi penting dalam kaitannya dengan pemasaran objek wisata (Warpani \& Warpani, 2007). Persepsi pengunjung Wisata Alam Pusri Danau Ranau perlu untuk dikumpulkan dengan adanya data tersebut maka akan menjadi bahan pertimbangan penting dalam pengembangan dan pengelolaan wisata tersebut. Tujuan dari penelitian ini adalah indentifikasi persepsi responden terhadap aspek alam dan lingkungan, aspek fasilitas dan pelayanan, aspek akomodasi dan aspek infrastruktur di Wisata Alam Pusri Danau Ranau.

\section{METODE}

Penelitian dilakukan di Wisata Alam Pusri Danau Ranau, di Desa Sukamarga, Kecamatan Buay Pematang Ribu Ranau Tengah, Kabupaten OKU Selatan, Provinsi Sumatera Selatan. Penelitian dilaksanakan pada bulan Agustus 2020. Alat yang digunakan dalam penelitian ini adalah alat tulis, kamera, laptop dan kuesioner tertutup. Objek penelitian ini adalah responden (pengunjung) Wisata Alam Pusri Danau Ranau. Metode pengambilan data dilakukan dengan menggunakan observasi dan kuesioner wawancara tertutup. Penentuan responden sebagai unit penelitian dilakukan dengan cara purposive sampling, yaitu memilih responden yang diambil keterangannya dengan pertimbangan-pertimbangan tertentu. Penentuan jumlah responden pengunjung menggunakan data jumlah kunjungan pada tahun 2019 yaitu 15.970 pengunjung, 
sehingga berdasarkan Rumus Slovin maka diperoleh sampel sebanyak 100 orang. Peta lokasi penelitian dapat dilihat pada Gambar 1.

Pengembangan Objek Wisata Pusri Danau Ranau dapat diwujudkan dengan mengacu pada 4 aspek sebagai pendukung wisata yaitu aspek alam dan lingkungan, persepsi akomodasi, persepsi infrastruktur dan persepsi fasilitas dan pelayanan. Persepsi wisatawan yang sudah didapatkan menggunakan one score one indicator dan skala likert disajikan kedalam bentuk grafik peniliaian one score one indicator dan skala likert. Penelitian ini menggunakan 5 skala penilaian, yaitu skor 1 = sangat tidak baik; skor 2 = tidak baik; skor 3 = cukup baik; skor $4=$ baik; dan skor 5 = sangat baik.

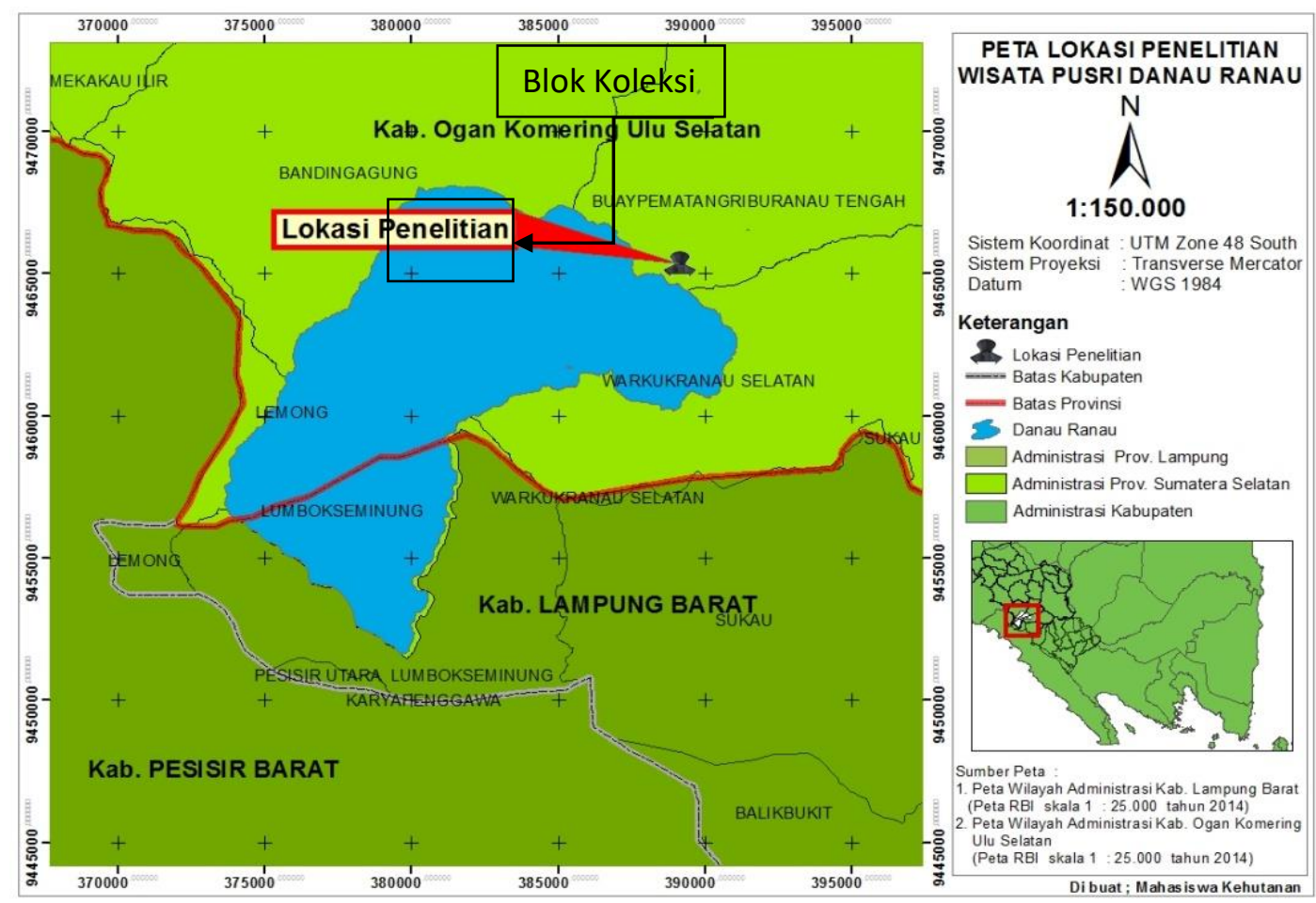

Gambar 1. Peta lokasi penetlitian Wisata Alam Pusri Danau Ranau.

Figure 1. Location map of Natural Tourism Pusri Lake Ranau.

\section{Kondisi Lokasi Penelitian}

HASIL DAN PEMBAHASAN

Menurut Sumino (2017), Danau Ranau merupakan danau terbesar kesebelas di Indonesia dan terbesar kedua di Pulau Sumatera setelah Danau Toba. Danau Ranau terletak di 2 (dua) wilayah yaitu Kabupaten Lampung Barat Provinsi Lampung dan Kabupaten Ogan Komering Ulu Selatan Provinsi Sumatera Selatan. Luas total dari Danau Ranau adalah $128 \mathrm{~km}$ termasuk luasan 85,33 km yang berada dalam wilayah Kabupaten OKU Selatan dan 42,67 km berada di wilayah Kabupaten Lampung Barat, kedalaman rata-rata 174,041 m, kedalaman maksimal 229 $\mathrm{m}$, volume air $21.95 \mathrm{~km}^{3}$ dan ketinggian permukaan $540,10 \mathrm{~m}$.

Secara administratif perairan Danau Ranau terbagi menjadi dua wilayah, yaitu: Perairan danau seluas $2.792,19$ ha $(22,12 \%)$ masuk kedalam wilayah administrasi Kabupaten Lampung Barat (Provinsi Lampung), dengan panjang garis sempadan danau 23,6 km. Perairan danau seluas 9.831 .33 ha $(77,88 \%)$ berada di wilayah administrasi Kabupaten OKU Selatan, Provinsi Sumatera Selatan. Panjang garis sempadan Danau Ranau mencapai 41,1 km. Danau Ranau 
tercipta dari gempa besar dan letusan vulkanik dari gunung berapi yang membuat cekungan besar. Terletak pada koordinat $4^{\circ} 51^{\prime} 45^{\prime \prime}$ Lintang Selatan (LS) dan 103⒌'50" Bujur Timur (BT) (Siregar, 2018).

Wisata Alam Pusri Danau Ranau terletak di Desa Sukamarga, Kecamatan Buay Pematang Ribu Ranau Tengah. Secara administratif, lokasi wisata ini berbatasan langsung dengan 2 (dua) desa, yaitu Desa Villa (di sebelah timur) dan Desa Tanjung Kemala (di sebelah selatan). Wisata Alam Pusri Danau Ranau didirikan pada tahun 1981 dengan kondisi pembukaan akses menuju wisata dan pada tahun 1987 PT. Sri Varian Wisata mengkomersilkan dan mengelola Wisata Alam Pusri Danau Ranau dengan luas wilayah sebesar 10,6 ha dan luas bagunan yaitu 2,6 ha dengan jumlah kamar 41 ruangan.

\section{Persepsi Wisatawan Wisata Alam Pusri Danau Ranau \\ 1. Aspek Alam dan Lingkungan}

Kawasan Objek Wisata Alam Pusri Danau Ranau memiliki daya tarik wisata alam tersendiri bagi wisatawan yang sedang melakukan perjalanan wisata. Persepsi wisatawan berperan penting untuk mengetahui manfaat yang dirasakan wisatawan. Penilaian wisatawan berdasarkan 5 alternatif jawaban yang ditawarkan terhadap aspek alam dan lingkungan disajikan pada Gambar 2.

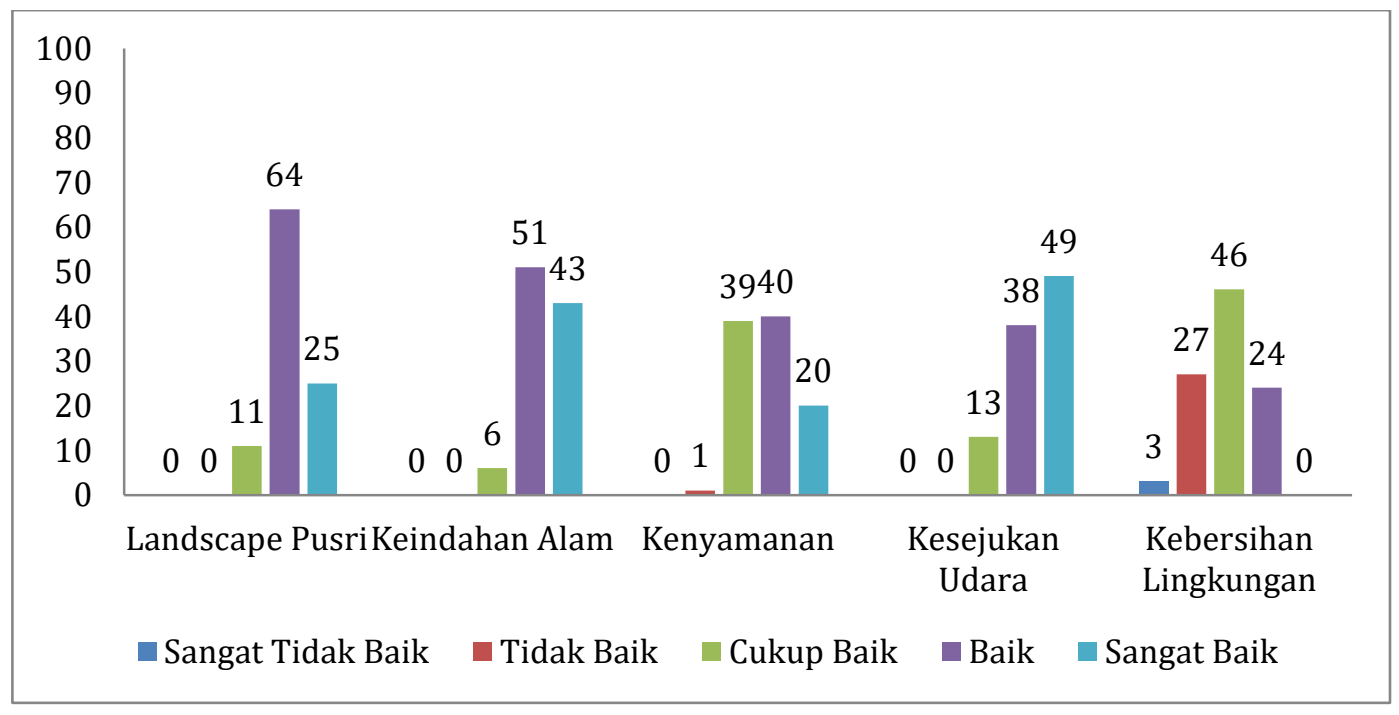

Gambar 2. Penilaian aspek alam dan lingkungan.

Figure 2. Assessment of natural and environmental aspects.

Berdasarkan data tersebut responden diberi kewenangan dalam berpendapat dan menilai mengenai wisata alam Pusri Danau Ranau. Penilaian terhadap aspek alam dan lingkungan mengenai landscape Pusri diperoleh sebanyak 64 dengan penilaian cukup baik, hal ini membuktikan bahwa responden sangat puas menikmati pemandangan yang disajikan di wisata ini dengan keindahan Danau Ranau dan juga Gunung Seminung. Bagian keindahan alam yaitu sebanyak 51 responden yang menjawab baik dan 43 responden yang menjawab sangat baik, hal ini karena wisata ini menyajikan keindahan alam yang masih baik sehingga memberikan ketenangan jiwa tersendiri terhadap wisatawan. Menurut Subangkit et al. (2014) wisatawan akan merasa puas dengan kondisi kebersihan dan keamanan wisata yang baik.

Bagian kenyamanan yaitu sebanyak 39 responden menilai cukup baik 40 responden menjawab baik dan 20 responden menjawab sangat baik diartikan bahwa Wisata Pusri memberikan 
kenyamanan kepada wisatawan yang berkunjung. Penilaian mengenai kesejukan udara yaitu sebanyak 13 responden menjawab cukup baik 38 responden menjawab baik dan 49 responden menjawab sangat baik untuk kesejukan udara di Pusri Danau Ranau memang masih baik sehingga wisatawan senang untuk berlama-lama diwisata ini dan terakhir mengenai kebersihan lingkungan yaitu sebanyak 3 responden menjawab sangat tidak baik 27 responden menjawab tidak baik 46 responden menjawab cukup baik dan 24 responden menjawab baik pada bagian ini wisataan belum puas mengenai sektor kebersihan lingkungan oleh karena itu kebersihan lingkungan harus lebih diperhatikan lagi oleh pengelola wisata. Upaya konservasi tidak dapat dilakukan secara maksimal tanpa ada dukungan dari masyarakat. Kegiatan ekowisata mengintegrasikan kegiatan pariwisata, konservasi, dan pemberdayaan masyarakat lokal (Prasetyo et al., 2019).

\section{Aspek Akomodasi}

Akomodasi merupakan suatu yang disediakan untuk memenuhi kebutuhan misalnya tempat menginap atau tempat tinggal sementara bagi orang yang bepergian. Akomodasi merupakan simpul penyaluran wisatawan dari tempat tinggal menuju lokasi objek wisata dengan objek wisata lainnya yang menjadi destinasi tujuan wisata (Nisa \& Haryanto, 2014). Menurut Evita et al. (2012), dalam kepariwisataan akomodasi merupakan suatu industri karena akomodasi dapat berupa suatu tempat atau kamar dimana orang-orang atau wisatawan dapat beristirahat atau menginap, mandi, makan dan minum serta menikmati jasa pelayanan dan hiburan yang tersedia. Penilaian berdasarkan persepsi wisatawan terhadap aspek akomodasi disajikan pada Gambar 3.

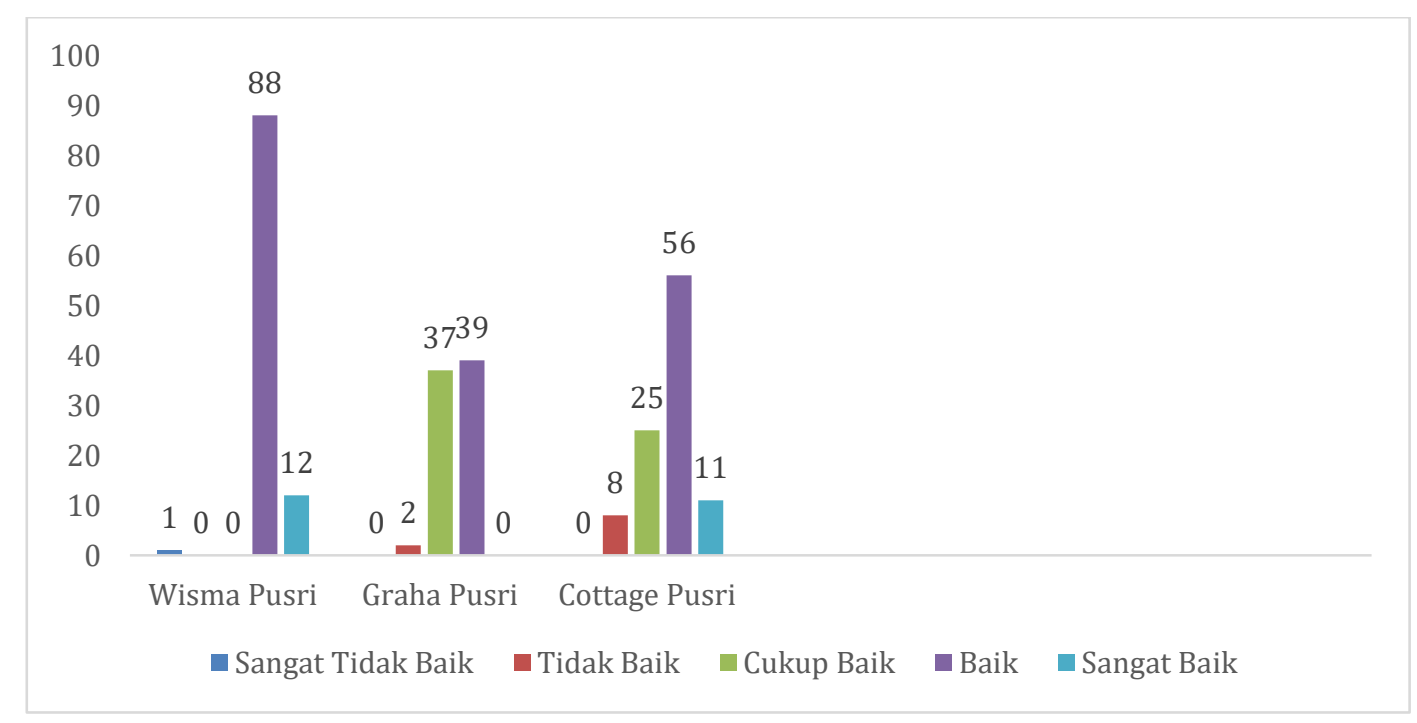

Gambar 3. Penilaian aspek akomodasi.

Figure 3. Assessment of accommodation aspects.

Persepsi wisatawan terhadap aspek akomodasi pada Wisata Alam Pusri Danau Ranau. Penilaian wisatawan, terhadap Wisma Pusri sebanyak 88 orang menjawab baik, hal ini sejalan dengan akomodasi wisma yang masih memiliki keadaan yang baik hanya saja masih kurangnya perawatan dari pihak pengelola. Persepsi wisatawan terhadap Graha Pusri, sebanyak 37 orang menjawab cukup baik dan 39 orang menjawab baik, dan penilaian wisatawan terhadap cottage yaitu, sebanyak 56 orang menjawab baik dan 11 orang menjawab sangat baik, respon positif responden terhadap akomodasi cottage yang ada di Wisata Pusri memperoleh penilaian sudah baik. 


\section{Aspek Infrastruktur}

Infrastruktur dapat dijelaskan sebagai suatu sistem fasilitas fisik yang mendukung kehidupan, keberlangsungan dan pertumbuhan ekonomi dan sosial suatu masyarakat atau komunitas. Pengembangan sektor pariwisata sangat terkait dan bergantung pada perkembangan infrastruktur yang tersedia. Peran infrastruktur menjadi sangat penting karena dengan pengembangan infrastruktur dan sistem infrastruktur yang tersedia dapat mendorong perkembangan sektor kepariwisataan. Data yang diambil pada aspek infrastruktur yang ada di Wisata Pusri Danau Ranau diataranya jalan utama, jalan setapak, area parkir, jaringan listrik, jaringan telepon dan sampah/limbah. Penilaian berdasarkan persepsi wisatawan terhadap aspek infrastruktur disajikan dalam Gambar 4.

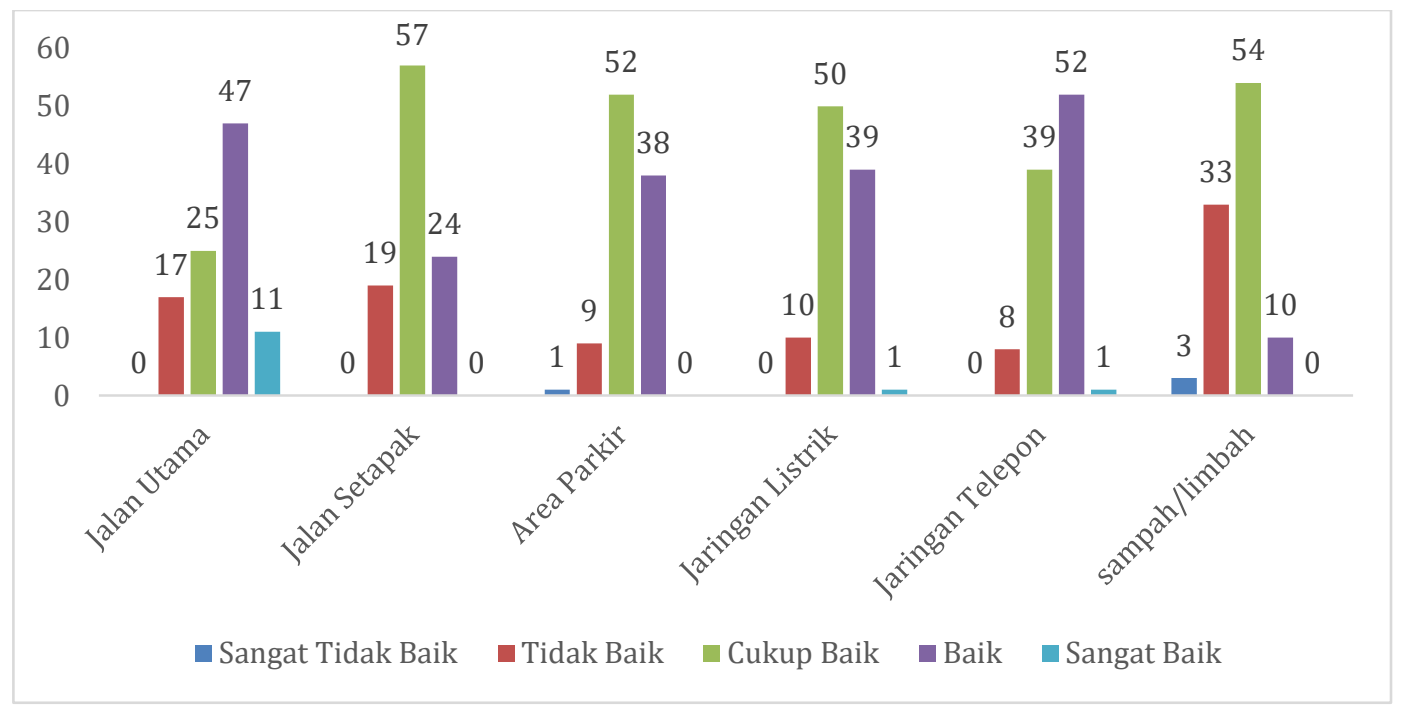

Gambar 4. Penilaian aspek infrastruktur.

Figure 4. Assessment of infrastructure aspects.

Berdasarkan data tersebut persepsi wisatawan mengenai jalan utama menuju Wisata Alam Pusri Danau Ranau menunjukkan persepsi baik dengan jumlah 47 orang dan sangat baik sejumlah 11 orang, hal ini dikarenakan jalan utama menuju wisata alam ini merupakan jalan yang menghubungkan antar dua provinsi sehingga kualitas infrastruktur jalan sangat diutamakan. Menurut Abdulhaji \& Yusuf (2016) aksesibilitas merupakan salah satu aspek penting yang mendukung pengembangan pariwisata, karena menyangkut pengembangan lintas sektoral. Tanpa dihubungkan dengan jaringan transportasi tidak mungkin suatu obyek wisata mendapat kunjungan wisatawan.

Pada bagian jalan setapak, wisatawan memberikan persepsi baik sejumlah 24 orang dan cukup baik sejumlah 57 orang, hal ini karena jalan setapak menuju Wisata Alam Pusri Danau Ranau tidak terlalu buruk dan masih layak untuk dilalui tanpa kendala. Jalan setapak di Wisata Pusri menggunakan bahan dasar material semen batako dan kondisi semua batako masih dalam keadaan baik. Untuk bagian area parkir, wisatawan memberikan persepsi baik sebanyak 38 orang dan 52 orang berpendapat area parkir yang disediakan wisata ini dalam keadaan cukup baik, hal ini menggambarkan bahwa pihak pengelola sudah maksimal dalam penyediaan area parkir. Menurut Pauwah et al (2013), tempat parkir merupakan aspek yang penting untuk diperhatikan karena dapat mempengaruhi kunjungan wisatawan saat ramai. 
Jaringan listrik berdasarkan persepsi wisatawan 39 orang menjawab baik dan 50 orang menjawab cukup baik hal ini menunjukkan bahwa penyedian listrik diwisata ini sudah baik. Berdasarkan persepsi wisatawan mengenai jaringan telepon didaerah wisata ini sudah dalam keadaan baik karena wisatawan tidak mengalami kendala dalam mengakses jaringan telepon atau jaringan internet dan persepsi wisatawan mengenai sampah/limbah yang berada diwisata pusri persepsi 10 orang menjawab baik dan 54 orang menjawab cukup baik pada bagian sampah wisatawan tidak begitu mengalami kendala karena sudah ada kotak sampah tetapi masih banyak wisatawan mengeluhkan karena pengelola kurang memperhatikan sampah pada bibir danau dan kondisi kebersihan sampah-sampah yang ada didanau. Menurut Sari et al. (2015) pengunjung cendrung untuk berwisata alam dengan kondisi wisata yang masih baik sera bernuansa alam.

\section{Aspek Fasilitas dan Pelayanan}

Fasilitas wisata dapat diartikan sebagai suatu sarana dan prasarana yang harus disediakan oleh pengelola untuk kebutuhan wisatawan (Putra, 2018). Wisatawan tidak hanya menikmati keindahan alam atau keunikan objek wisata saja melainkan memerlukan sarana dan prasarana dalam berwisata. Fasilitas dan pelayanan akan meningkatkan daya tarik serta minat dalam berkunjung wisatawan. Berdasarkan persepsi wisatawan terhadap aspek fasilitas dan pelayanan dapat dilihat pada Gambar 5.

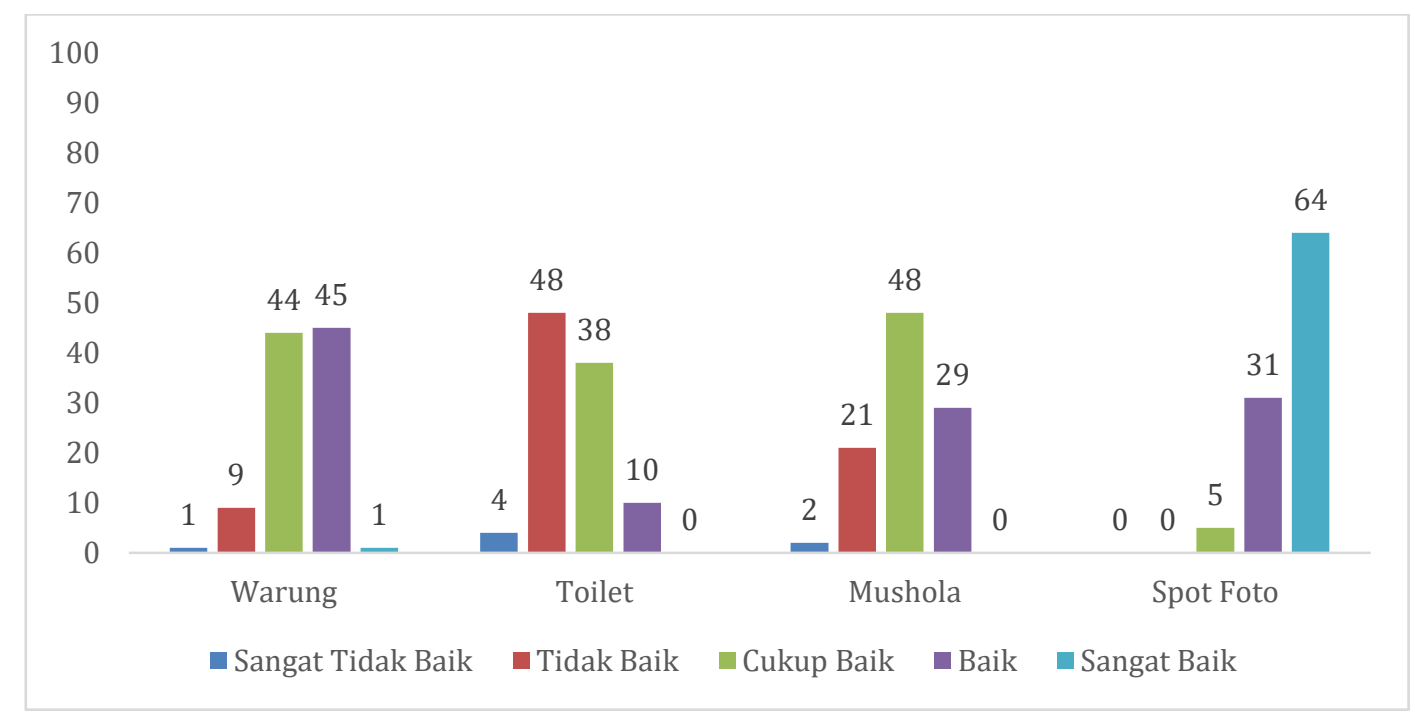

Gambar 5. Penilaian aspek fasilitas dan pelayanan.

Figure 5. Assessment of aspects of facilities and services.

Persepsi wisatawan terhadap fasilitas dan pelayanan pada bagian penyediaan warung makan sudah baik karena berdasarkan hasil observasi keberadaan warung makan sudah merata disetiap objek wisata sehingga waisatawan tidak kesulitan mencari makan. Toilet mendapatkan penilaian tidak baik sebanyak 48 dan penilaian baik sebanyak 38 dari persepsi wisatawan, hal ini dikarenakan hanya ada satu spot toilet yang berada ditengah areal wisata dan masih kurangnya perawatan dari pihak pengelola. Menurut Wiradipoetra \& Brahmanto (2018) kerusakan fasilitas akibat kurangnya perawatan dinilai sebagai pemicu persepsi negatif wisatawan terhadap daya tarik wisata, sehingga berdampak pada kurangnya minat untuk berkunjung. 
Persepsi wisatawan terhadap mushola cukup baik hal ini karena kondisi fisik mushola yang kecil namun cukup nyaman untuk melaksanakan ibadah sholat. Hal ini sejalan dengan pernyataan Wahyulina et al (2018) bahwa tempat ibadah dan toilet menjadi sarana paling penting yang diinginkan oleh para wisatawan yang berkunjung kesuatu tempat destinasi. Keunggulan di Wisata Alam Pusri Danau Ranau yaitu pada area sport foto karena dari hasil pengambilan data dilapangan 64 orang menjawab sangat baik hal ini membuktikan bahwa wisata pusri memiliki sport foto menarik yang menjadikan daya tarik tersendiri bagi wisata.

\section{Nilai Rata-rata Persepsi Wisatawan}

Penilaian wisatawan terhadap suatu objek wisata sangat diperlukan yang berguna untuk mengetahui dimana letak kekurang pada suatu objek wisata. Menurut Santoso (2013), evaluasi kinerja sangat penting untuk menilai dan mempelajari bagaimana proses pencapaian misi guna perbaikan pelaksanaan program/kegiatan di masa mendatang. Melalui evaluasi kinerja dapat dianalisis faktor-faktor penunjang keberhasilan bahkan penyebab kegagalan dalam pelaksanaan program/kegiatan.

Berdasarkan persepsi wisatawan, rata-rata nilai persepsi wisatawan Wisata Alam Pusri Danau Ranau mengenai aspek akomodasi, alam dan lingkungan, infrastruktur, fasilitas dan pelayanan dapat dilihat pada Gambar 6.

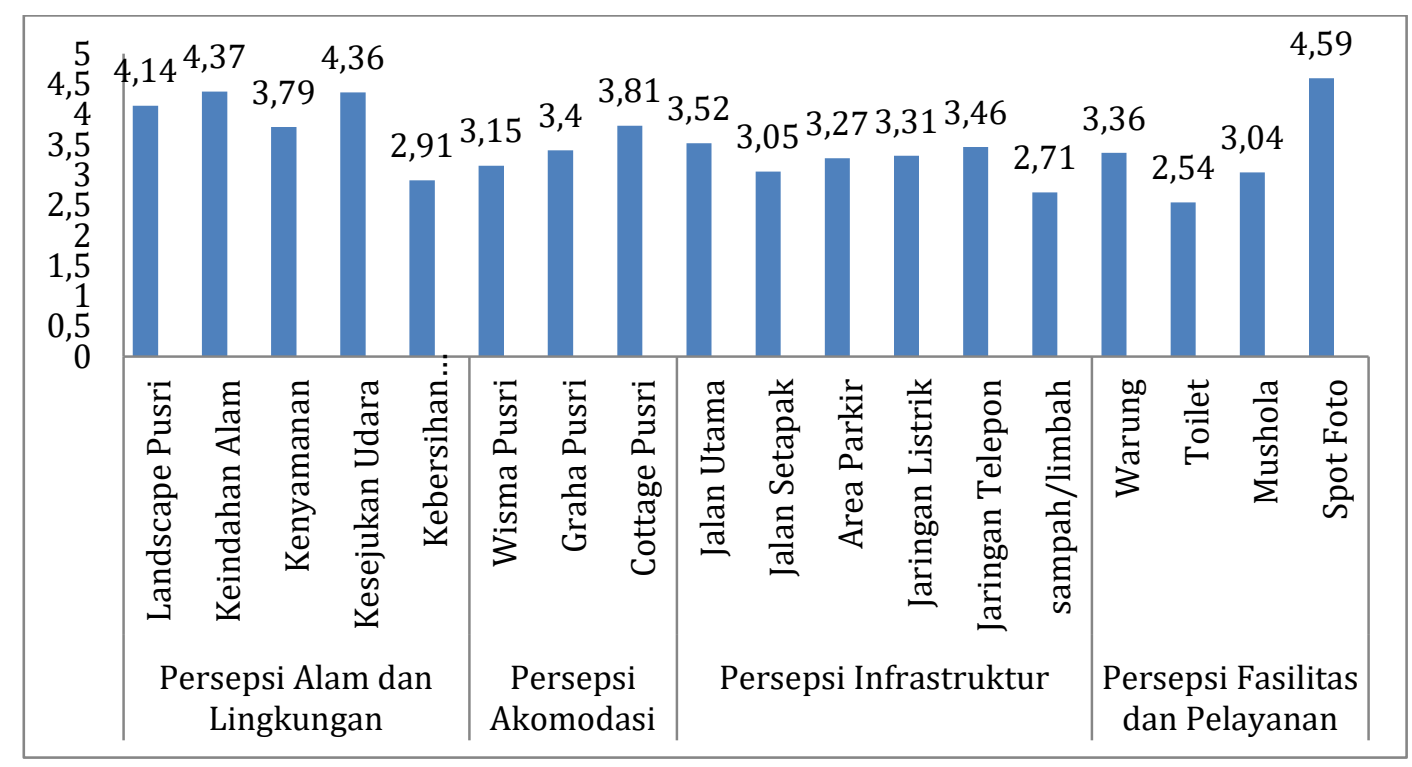

Gambar 6. Nilai rata-rata persepsi wisatawan.

Figure 6 . The average value of traveler perception.

Nilai rata-rata persepsi wisatawan Wisata Alam Pusri Danau Ranau.terhadap aspek-aspek dan setiap unsurnya sangat bervariasi dan dapat dijadikan sebagai alasan dilakukannya evaluasi terhadap wisata ini. Berdasarkan data grafik yang disajikan pada gambar diatas, penilaian responden pada aspek alam dan lingkungan, akomodasi, fasilitas dan pelayanan serta infrastruktur dengan rata-rata disetiap unsur terhadap aspeknya dengan memberikan penilaian dengan skor cukup beragam. Unsur yang hampir mendapati nilai sempurna terdapat pada aspek fasilitas dan pelayanan yaitu pada unsur sport foto dengan skor 4.59 , hal ini disebabkan karena Wisata Alam Pusri Danau Ranau memberikan fasilitas spot berfoto yang menarik membuat responden memberikan penilaian yang baik. 
Skor terendah pada unsur di setiap aspek-aspeknya, kebersihan lingkungan menjadi evaluasi yang harus diperhatikan karena melihat persepsi responden yang kurang baik agar dilakukannya evaluasi agar terciptanya keselarasan yang diinginkan baik dari pengelola maupun wisatawan yang berkunjung. Nilai rata-rata terhadap kebersihan yaitu 2,91, pengelolaan sampah yaitu 2,71 dan toilet yaitu 2,54.

\section{Perbandingan Nilai Persepsi Wisatawan}

Penilaian skala likert persepsi wisatawan terhadap Wisata Alam Pusri Danau Ranau pada berbagai aspek, diantaranya aspek alam dan lingkungan, akomodasi, infrastruktur dan fasilitas dan pelayanan. Perbandingan nilai persepsi wisatawan dianggap penting untuk diketahui karena dari perbandingan persepsi wisatawan tersebut dapat mengetahui pendapat wisatawan terhadap suatu wisata dan membantu pengelola dalam mengembangkan perencanaan pembangunan wisata yang berfokus pada hal apa yang harus didahulukan sehingga dapat memotivasi peningkatan jumlah kunjungan dari pembenahan berbagai fasilitas layanan serta merancang strategi pemasaran yang baik.

Wibowo (2015) menyatakan bahwa pengelola perlu membenahi layanan yang ada dan melakukan berbagai inovasi layanan untuk menciptakan persepsi positif terhadap kualitas layanan maupun secara keseluruhan. Berdasarkan persepsi wisatawan perbandingan nilai persepsi wisatawan terhadap objek dan daya tarik, aspek akomodasi, alam dan lingkungan, infrastruktur, fasilitas dan pelayanan dapat dilihat pada Gambar 7.

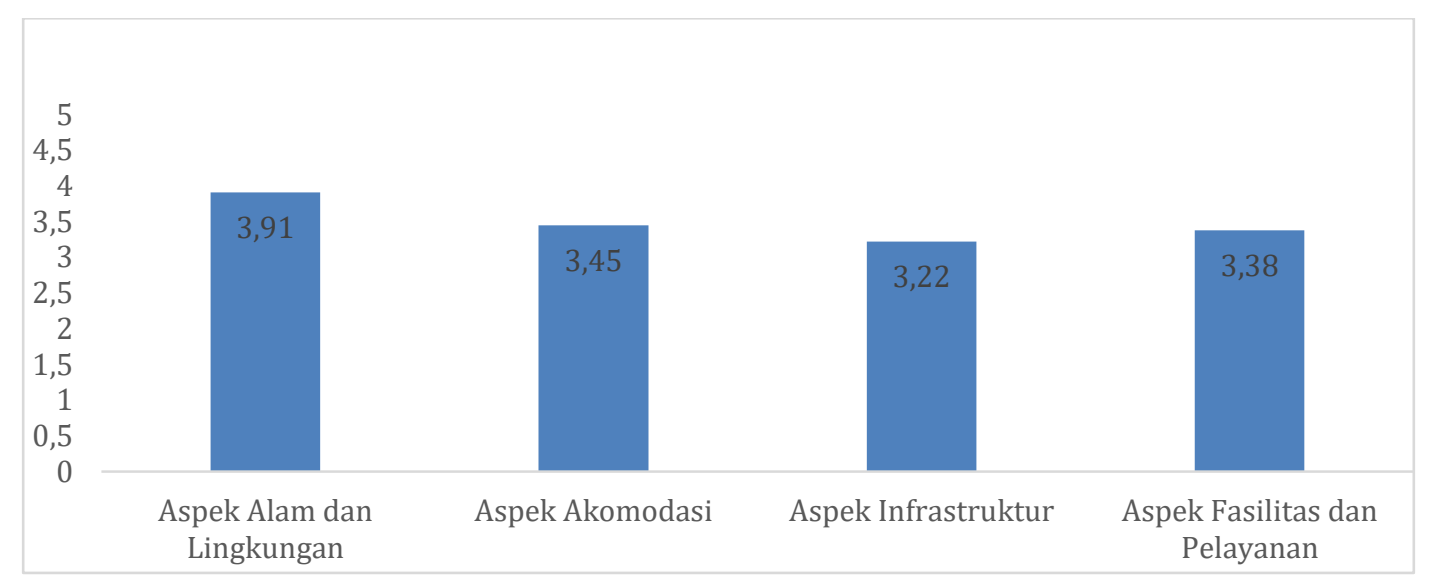

Gambar 7. Perbandingan persepsi wisatawan Wisata Alam Pusri Danau Ranau.

Figure 7. Comparison of tourist perception of Pusri Nature Tourism Lake Ranau.

Perbandingan nilai persepsi wisatawan Wisata Alam Pusri Danau Ranau terhadap aspek-aspek di Wisata Alam Pusri Danau Ranau sangat bervariasi, tetapi penilaian tersebut tidak terlihat jauh berbeda untuk setiap aspeknya. Berdasarkan data grafik yang disajikan pada Gambar 7 diatas, penilaian responden pada aspek alam dan lingkungan, akomodasi, fasilitas dan pelayanan, infrastruktur memberikan penilaian dengan skor cukup baik karena 3 aspek yang dinilai memiliki nilai 3-3,5 yang dibulatkan menjadi score 3,5 dan masih perlu banyak pembenahan bagi setiap aspek pada Wisata Pusri agar menjadi wisata yang lebih baik lagi.

Skor tertinggi dari keempat aspek tersebut yaitu pada aspek alam dan lingkungan, yaitu 3,91 hal ini terjadi karena Wisata Alam Pusri Danau Ranau memiliki panorama alam yang indah dengan dihiasi oleh Danau Ranau dan Gunung Seminung menjadi daya tarik tersendiri bagi wisatawan yang datang. Nilai persepsi wisatawan terendah dengan nilai 3,22 yaitu pada aspek 
infrastruktur, hal ini menunjukkan bahwa Wisata Alam Pusri Danau Ranau memiliki aksesibilitas yang cukup baik dan masih banyak kebutuhan wisatawan yang belum dapat terpenuhi.

\section{KESIMPULAN DAN SARAN}

Responden memberikan presepsi penilaian yang bervariasi terhadap Wisata Alam Pusri Danau Ranau untuk setiap aspek penilaian diantaranya: aspek alam dan lingkungan sebesar 3,91 (cukup baik), aspek akomodasari sebesar 3,45 (cukup baik), aspek infrastruktur sebesar 3,22 (cukup baik) dan aspek fasilitas dan pelayanan sebesar 3,38 (cukup baik). Unsur yang harus diperhatkan Wisata Alam Pusri Danau Ranau yaitu pada kebersihan lingkungan karena responden masih belum puas terhadap unsur tersebut yang mana dapat dilihat dari hasil nilai rata-rata terhadap kebersihan sebesar 2,91 (tidak baik) sedangkan pengelolaan sampah sebesar 2,71(tidak baik) dan toilet sebesar 2,54 (tidak baik). Penelitian ini berguna sebagai referensi mengenai persepsi wisatawan dalam pengembangan pariwisata alam serta menjadi pertimbangan dalam perencanaan pengembangan wisata kearah yang lebih baik.

\section{DAFTAR PUSTAKA}

Abdulhaji, S., \& Yusuf, I.S.H. (2016). Pengaruh Atraksi, Aksesibilitas, dan Fasilitas terhadap Citra Objek Wisata Danau Tolire Besar di Kota Ternate. Jurnal Penelitian Humano. 7(2): 134-148.

Evita, R., Sirtha, I.N., \& Sunartha, I.N. (2012). Dampak perkembangan pembangunan sarana akomodasi wisata terhadap pariwisata berkelanjutan di Bali. Jurnal IImiah Pariwisata. 3(4): 101112.

Kotler, P. (2005). Manajemen Pemasaran. PT. Index Kelompok Gramedia. Jakarta. 382 hlm.

Nisa, A.F., \& Haryanto, R. (2014). Kajian Keberadaan Wisata Belanja Malioboro terhadap Pertumbuhan Jasa Akomodasi di Jalan Sosrowijayan dan Jalan Dagen. Jurnal Teknik PWK. 1(4): 933-948.

Oktaviantari, N.P.E., Damiati, \& Suriani, N.M. (2019). Potensi Wisata Alam Air Terjun Kuning sebagai Daya Tarik Wisata Alam di Kawasan Desa Taman Bali, Kecamatan Bangli, Kabupaten Bangli. Jurnal Bosaparis: Pendidikan Kesejahteraan Keluarga. 10(2): 136-146.

Prasetya, D.B., \& Ansar, Z. (2017). Pengembangan Desa Wisata Berbasis Community Based Tourism pada Kawasan Danau Ranau Lumbok Seminung Lampung Barat. Jurnal Plano Madani. 6(1): 60-72.

Prasetyo, D., Darmawan, A., \& Dewi, B.S. (2019). Persepsi wisatawan dan individu kunci tentang pengelolaan ekowisata di Lampung Mangrove Center. J. Sylva Lestari. 7(1): 22-29.

Putra, A.E., Yoza, D., \& Mardhiansyah, M. (2018). Analisis Daya Minat Pengunjung terhadap Wisata Alam Air Terjun Denalo Maras Kecamatan Batang Cenaku Kabupaten Indragiri Hulu Provinsi Riau. Jurnal Online Mahasiswa Faperta UR. 5(1): 1-10.

Rosida, F. (2018). Pengaruh Harga dan Fasilitas Terhadap Kunjungan Wisata di Pantai Air Bangis Kabupaten Pasaman Barat. Skripsi. Universitas Islam Negeri Sumatera Utara. 199 hlm. 
Santoso, S. (2013). Analisis Laporan Akuntabilitas Kinerja pada Dinas Kebudayaan dan Pariwisata Provinsi Sulawesi Utara. Jurnal Emba. 1(4): 160-170.

Sari, H.P., Setiawan, A., Winarno, G.D., \& Harianto, S.P. (2018). Persepsi Pengunjung untuk Pengembangan Hutan Kota Metro sebagai Objek Wisata Alam. Gorontalo Journal of Forestry Research. 1(2): 35-48.

Sari, Y., Yuwono, S.B., \& Rusita. (2015). Analisis Potensi dan Daya Dukung Sepanjang Jalur Ekowisata Hutan Mangrove di Pantai Sari Ringgung Kabupaten Pesawaran Lampung. Jurnal Sylva Lestari. 3(3): 31-41.

Setiawan, I.B.D. (2015). Identifikasi Potensi Wisata Beserta 4A (Attraction, Amenity, Accessibility, Ancilliary) di Dusun Sumber Wangi, Desa Pemuteran, Kecamatan Gerokgak, Kabupaten Buleleng, Bali. Skripsi. Universitas Udayana Denpasar. $33 \mathrm{hlm}$.

Siregar, S.M. (2018). Situs-situs Megalitik di Desa Padangratu Kabupaten OKU Selatan (Gambaran Adaptasi Lingkungan). Jurnal Forum Arkeologi. 31(2): 147-158.

Subangkit, L., Bakri, S., \& Herwanti, S. (2014). Faktor-faktor Kepuasaan Pengunjung di Pusat Konservasi Gajah Taman Nasional Way Kambas Lampung. Jurnal Sylva Lestari. 2(3): 101-110.

Sumino, Mude, H., Alam, S.S., \& Oktaviani, D. (2017). Protected, Prohibited, and Invasive Fish Diversity and Distribution in Ranau Lake of West Lampung District. Jurnal IImu Perikanan dan Sumberdaya Perairan. 6(1): 553-558.

Wahyulina, S., Darwini, S., Retnowati, W., \& Oktaryani, S. (2018). Persepsi Wisatawan Muslim terhadap Sarana Penunjang Wisata Halal di Kawasan Desa Sembalun Lawang Lombok Timur. Jurnal Magister Manajemen Unram. 7(1): 27-39.

Warpani, S.P., \& Warpani, I.P. (2007). Pariwisata dalam Tata Ruang Wilayah. ITB Press. Bandung. $244 \mathrm{hlm}$.

Wibowo, A.J.I. (2015). Persepsi Kualitas Layanan Museum di Indonesia. Jurnal Manajemen, 15(1): 18-40.

Wiradipoetra, F.A., \& Brahmanto, E. (2016). Analisis Persepsi Wisatawan Mengenai Penurunan Kualitas Daya Tarik Wisata terhadap Minat Berkunjung. Jurnal Pariwisata. 3(2): 133-137.

Yumsinah, S. (2017). Pengaruh Jumlah Wisatawan Terhadap Pendapatan Asli Daerah di Kabupaten Pandeglang Tahun 2005-2015. Skripsi. Universitas Islam Negeri Sultan Maulana Hasanuddin. Banten. $62 \mathrm{hml}$. 